\title{
Integrating conservation, restoration and land-use planning in islands-An illustrative case study in Réunion Island (Western Indian Ocean)
}

\author{
Erwann Lagabrielle ${ }^{\mathrm{a}, \mathrm{b}, \mathrm{c}, *}$, Mathieu Rouget $^{\mathrm{d}, \mathrm{e}}$, Thomas Le Bourgeois ${ }^{\mathrm{c}, \mathrm{j}}$, Karine Payet ${ }^{\text {c,e,f }}$, \\ Laurent Durieux $^{\mathrm{g}}$, Stéphane Baret ${ }^{\mathrm{h}}$, Joël Dupont ${ }^{\mathrm{i}}$, Dominique Strasberg ${ }^{\mathrm{c}}$ \\ a Nelson Mandela Metropolitan University, Saasveld Campus, Private Bag X6531, George 6530, South Africa \\ b Institute for Research and Development (IRD), UMR 128 ESPACE-DEV, IRD Réunion, BP 50172, 97492 Sainte-Clothilde Cedex, France \\ ' UMR PVBMT, CIRAD, Université de la Réunion, 7 chemin de l'IRAT, Ligne Paradis 97410, Saint-Pierre, France \\ d South African National Biodiversity Institute, Private Bag X101, Pretoria 0001, South Africa \\ e Department of Plant Science, University of Pretoria, Pretoria 0002, South Africa \\ ${ }^{\mathrm{f}}$ Department of Conservation Ecology and Entomology, Stellenbosch University, Private Bag X1, Matieland 7602, South Africa \\ g Institute for Research and Development (IRD), UMR 128 ESPACE-DEV, IRD Brésil, CP 7091 - Lago Sul, 71619, 970 Brasilia (DF), Brazil \\ h Parc national de La Réunion, 112 rue Sainte Marie, 97400 Saint-Denis, France \\ i Société Réunionnaise d'Etude et de Protection de l'Environnement, 30 rue des Deux-Canons, 97490 Sainte-Clothilde, France \\ j UMR AMAP, CIRAD, TA A51/PS2, boulevard de la Lironde, 34730 Montpellier Cedex 5, France
}

\section{A R T I C L E I N F O}

\section{Article history:}

Received 21 April 2010

Received in revised form 24 January 2011

Accepted 5 February 2011

Available online $\mathrm{xxx}$

\section{Keywords:}

Biodiversity

GIS

Cost optimisation

Corridors

Protected areas

Invasion

\begin{abstract}
A B S T R A C T
This paper describes an operational protocol for integrating conservation and restoration with land-use planning in islands. Conservation challenges are intensified in insular systems due to higher ecosystem vulnerability, limited spatial options, low data availability, rapid land-use change and, globally, shortterm vision planning. Our operational planning protocol integrates ecological and socio-economic factors to identify the best spatial options for conserving and restoring biodiversity, inside and outside extant reserves, while minimising future land-use conflicts. Conservation and restoration targets are formulated for species, habitats and ecological processes that support biodiversity. An optimal network of priority sites is selected to achieve those targets across the landscape. The prioritisation process integrates a Conservation Costs Index to optimise conservation and restoration investments. We discuss the outcomes of the planning protocol in terms of site prioritisation, stakeholders' participation and general implications for spatial planning in insular systems. As with many islands, the study area of Réunion Island has experienced rapid urban and agricultural expansion, which threatens its unique biodiversity. Forty three per cent of the island is currently protected in a National Park but only half of this reserve network contributes to the achievement of targets. An additional $21 \%$ of land should be conserved mainly to ensure the persistence of ecological connections between the marine, terrestrial and freshwater realms. Finally we emphasize that our method doesn't substitute the land-use planning debate but is aimed to better prepare the conservation sector for negotiating future land-use allocation with other socio-economic sectors in islands.
\end{abstract}

(C) 2011 Elsevier B.V. All rights reserved.

\section{Introduction}

Spatial planning in islands must carefully balance ecosystem persistence requirements with insular development. Over the last century, insular ecosystems have become some of the most

\footnotetext{
* Corresponding author at: Nelson Mandela Metropolitan University, Saasveld Campus, Private Bag X6531, George 6530, South Africa. Tel.: +00 262262299901.

E-mail addresses: erwann.lagabrielle@gmail.com, erwann.lagabrielle@ird.fr (E. Lagabrielle), mathieu.rouget@up.ac.za(M. Rouget),thomas.le_bourgeois@cirad.fr(T. Le Bourgeois), karine.kp@gmail.com (K. Payet), laurent.durieux@ird.fr (L. Durieux), stephane.baret@reunion-parcnational.fr (S. Baret), srepenreunion@wanadoo.fr (J. Dupont), dominique.strasberg@univ-reunion.fr (D. Strasberg).
}

restricted and threatened in the world (Mueller-Dombois and Loope, 1990). For instance, more than $60 \%$ of documented vertebrate extinctions have occurred on islands (Diamond, 1989; Case et al., 1992). Islands ecosystems are particularly rich in endemic species, and contribute disproportionately to global biodiversity (Stattersfield and Capper, 2000). Conservation and restoration in islands is a major challenge since 10 of the 34 terrestrial biodiversity hotspots listed by Conservation International are wholly comprised of islands (Mittermeier et al., 2005; Cook et al., 2006). To address this challenge, we developed and tested a spatial planning protocol to optimise conservation and restoration investments in the landscape while minimising potential conflicts with other landuses in islands.Confounding ecological and anthropogenic factors 
have been cited to explain unprecedented rate of biodiversity loss in islands. This includes the rarity of spatial options for biodiversity persistence (Simberloff, 1995; Whittaker et al., 2001), a higher vulnerability of ecosystems to invasions (Mueller-Dombois and Loope, 1990; Fritts and Rodda, 1998), and higher rates of land conversion (Cudihhy and Stone, 1990). Poor spatial planning in insular ecosystems has led to disastrous, rapid and irreversible biodiversity loss (Dolisca et al., 2007). In addition, several factors hinder the implementation of conservation actions in insular regions, i.e. poverty, poor knowledge and data, and, overall, insufficiently integrated conservation strategies.

Conservation plans initiated in insular regions often focused on biodiversity only and ignored socio-economic factors that guide effective conservation (Veech, 2003). This often resulted in unsustainable conservation strategies due to conflicts between islanders' interests and conservation (Novy-Hildesley, 2001). For instance, such conflicts hindered conservation implementation in the Galapagos (Grenier, 2000) and in New-Zealand (Young, 2004). Although islands share common social and ecological traits with continental areas, many conservation challenges are intensified in insular systems.

Following systematic conservation planning principles (Balmford, 2003; Margules and Pressey, 2000), our protocol aims to identify ex ante the best spatial options for conserving and restoring a representative sample of biodiversity features and ecosystem processes inside and outside an extant reserves network, while minimising conflicts with other land uses. After presenting conservation challenges in Réunion Island (Section 2), we describe the planning protocol (Section 3): mapping habitats, species and biodiversity processes (Section 4 ), setting conservation and restoration targets (Section 5), identifying priority sites for conservation and restoration (Section 6). Outcomes of the plans are analysed in Section 7. Finally, we propose implementation mechanisms toward a better integration of conservation and restoration issues within land-use planning in Réunion Island (Section 8), and more generally in insular regions (Section 9).

\section{Conservation and land-use planning challenges in Réunion Island}

Réunion Island $\left(2512 \mathrm{~km}^{2}\right)$ is a small French island located in the Indian Ocean, $200 \mathrm{~km}$ South-West of Mauritius and $700 \mathrm{~km}$ to the East of Madagascar (Fig. 1). Its steep volcanic relief reaches $3070 \mathrm{~m}$ in the centre of the island. A third of its areas is still covered by native vegetation ranging from lowland rainforest to subalpine grassland (Strasberg et al., 2005).

The island has long been recognised as a global priority for conservation owing to its high concentration of endemic taxa, especially of plants. Forty six per cent of the 843 species of vascular plants species in Réunion Island are endemic to the Mascarene region that is comprised of Mauritius and Rodrigues Island (Cadet, 1980; Conservatoire Botanique National de Mascarin, 2008). Réunion Island is comprised in a terrestrial and a marine biodiversity hotspot (Roberts et al., 2002; Mittermeier et al., 2005).

At present, more than $80 \%$ of the 802,000 inhabitants (INSEE, 2009) live on the coastal fringe where most of the socio-economic activities are concentrated. Population has been increasing at rate of $1.5 \%$ per year since 2000 and is predicted to reach 1 million inhabitants in 2030 (INSEE, 2009). European Development Funds boosted the economy of the island since the 1990's. Concomitantly, urban areas expanded by $189 \%$ over the period from 1989 to 2002 (Durieux et al., 2008) and available land became a rare and coveted resource. Below $1000 \mathrm{~m}$, landscapes are now expected to fulfil multiple functions (i.e. urbanisation, agriculture production and ecosystem conservation) and this causes conflicts among stakeholders about their planning and management (van der Valk, 2002).

Since the European occupation of the island (in 1665), lowland habitats $(<1000 \mathrm{~m})$ are almost fully transformed, except on harsh slopes and ravines (Gigord et al., 1999) (Fig. 1). As with other insular regions, biodiversity in Réunion is facing escalating threats that have already led to the extinction of 30 of 45 vertebrate species (Mourer-Chauvire et al., 1999). Habitat degradation by invasive alien species is an important threat to its endemic biodiversity (MacDonald et al., 1991; Baret et al., 2006). Ecosystem conversions by urbanisation and agriculture (mainly sugar cane and market gardening) are destroying remnant pristine vegetation patches in the lowlands, while forestry and native forest clearing for cattle breeding are major threats to biodiversity in the uplands (Strasberg et al., 2005). Since the creation of a National Park in $2007,43 \%$ of the area of the island is protected (Table 1 ). However, the reserve network is biased toward the uplands: the mean altitude of reserves is $1306 \mathrm{~m}$ versus $873 \mathrm{~m}$ for the whole island. With very few protected areas in the lowlands, the persistence of biodiversity in Réunion Island depends heavily on the successful integration of conservation and restoration strategies with land-use planning.

Future challenges for land-use planning in Réunion Island further include the control of urban sprawl and the protection of agricultural land from conversion by urbanisation. A regional development plan ("Schémad'AménagementRégional": hereafter referred to as SAR) rules the allocation of land uses for the whole island. The SAR developed in 1995 was under revision at the time of this analysis. Therefore, our objective was to produce conservation and restoration recommendations that could inform the SAR revision process. In addition there was a demand from the National Park authorities to identify priority areas for conservation and restoration inside the National Park boundaries.

\section{Planning protocol overview}

Our conservation and restoration planning protocol is based on systematic conservation planning principles (Margules and Pressey, 2000). As a first step, the conservation and land-use challenges were assessed and the institutional demand for spatial planning was identified during preparatory meetings with stakeholders from the urban, agriculture and conservation sector and scientists (Section 2). As a second step, we gathered spatial data on biodiversity for three different types of biodiversity features, i.e.(1) pristine habitats, (2) endemic species and (3) spatial components of ecological and evolutionary processes (Section 4). Conservation and restoration targets were formulated for those features (Section 5). After assessing the level of target achievement in existing conservation areas (i.e. a "gap analysis"), we identified additional priority areas to meet targets while minimising costs associated with conservation implementation, management, restoration and current and future land-use trends (Section 6). This was done using a site selection algorithm embedded in MARXAN software (Ball and Possingham, 2000). The site selection process follows eight stages (Table 3 ) that achieve incremental conservation and restoration targets into a spatial network of priority sites (see Section 7). Finally, we identified implementation mechanisms to better integrate conservation and restoration opportunities with land-use planning, inside and outside the existing reserve system (Section 8.4). The results of the site selection process plus the implementation recommendations constitute what we refer to as the "conservation and restoration plan".

The plan was developed through a participatory process. An advisory team of 10 professionals, constituted mainly of scientists (i.e., geographer, anthropologist, agronomist, modeller and ecologist), but also staff of the National Park authorities were 

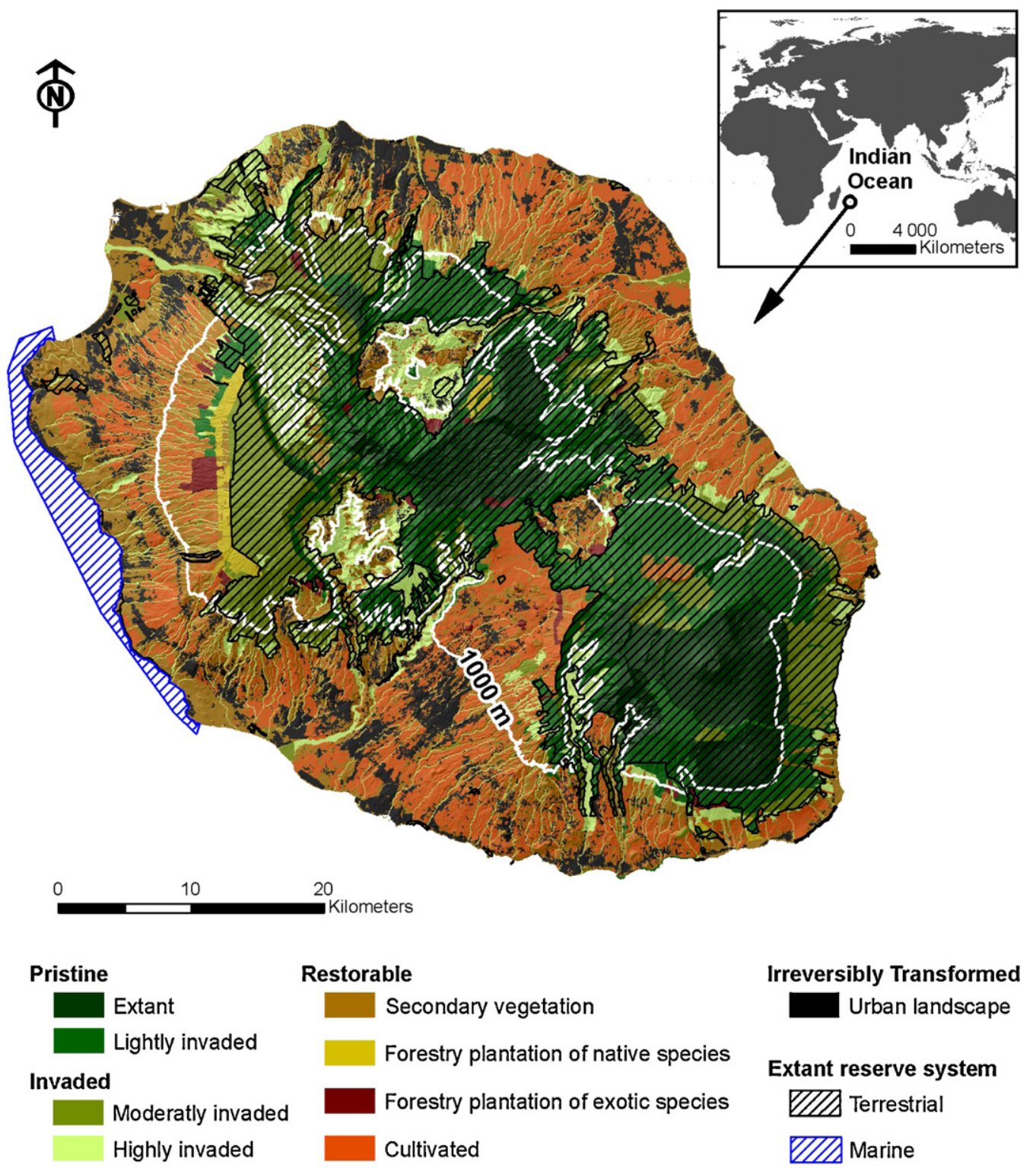

Fig. 1. Habitat transformation and reserves distribution in Réunion Island (from Strasberg et al., 2005).

Table 1

Protected areas categories in Réunion Island (terrestrial only). Spatial overlaps occur between protected areas.

\begin{tabular}{|c|c|c|c|}
\hline IUCN category type & Protected areas category & Area $\left(\mathrm{km}^{2}\right)$ & (\% of island's area) \\
\hline Type I & Biological forest reserve & 278 & 11.0 \\
\hline Type II & Core area of the National Park (including cultivated and inhabited areas) & 1048 & 41.7 \\
\hline \multirow[t]{4}{*}{ Type IV } & Nature reserve & 38 & 1.5 \\
\hline & Biotope reserve & 20 & 0.8 \\
\hline & Biological reserve of the National Forest Office & 76 & 3.0 \\
\hline & Sites of the Conservatoire du Littoral (coastal conservation agency) & 8 & 0.3 \\
\hline Total & & 1071 & 42.6 \\
\hline
\end{tabular}

consulted during workshops and individual interviews. Institutions involved in the land-use planning debate on the island were informed of the on-going conservation planning process throughout regular meetings and presentations. The strategy for the participation of stakeholders is specifically discussed in Lagabrielle et al. (2010): they concluded that the participatory development of land-use simulation models should be promoted to explore alternative scenarios for biodiversity conservation with stakeholders. They also showed that this participatory planning approach should be gradual and sequential to fit into public decision-making processes.

\section{Mapping biodiversity}

\subsection{Habitats}

In areas where available data on biodiversity are poor or limited, a coarse-filter approach to mapping biodiversity is recommended 
(Margules and Pressey, 2000). To this purpose, habitats act as good surrogates for overall biodiversity (Lombard et al., 2003).

To develop the habitat map in Réunion Island we integrated expert judgements with remote sensing data and GIS analysis. Pristine habitats were extracted from Strasberg et al. (2005). These were modeled using slope, altitude and rainfall data combined with aerial photography analysis (Strasberg et al., 2005).

As we aimed to develop a habitat map compatible with conventional land-use products, we combined GIS data on urbanisation and agriculture by collaborating with institutions involved in the land-use planning debate. The GIS layer on urban areas was provided by the Regional Urban Planning Agency (AGO$\mathrm{RAH}$ ). GIS layers on agriculture (cane, other crops and pastures) were validated by the Regional Agriculture Council (ChambreRégionaled'Agriculture). We integrated those GIS datasets following a set of rules defined with the participants, with urban areas superimposing all other features.

We mapped a system of 44 habitat classes, including 21 pristine classes (Fig. 1). Habitat classes, their current and past extent, are detailed in Appendix A. Each habitat class - including urban and agricultural areas - was attributed a transformation status by conservation experts (Table 2). The transformation status categories were derived from Strasberg et al. (2005) and Baret et al. (2006): extant (i.e. pristine), invaded (pristine remnants but alien species covering more than $50 \%$ of the under storey and more than $90 \%$ of the canopy), restorable (secondary vegetation and agricultural areas) and irreversibly transformed (urban areas).

\subsection{Species}

Due to time and budgetary limitations, we only used existing species datasets. We concentrated our data collection effort on threatened species. Unsurprisingly, these were distributed almost exclusively in lowlands where habitat transformation is the most prominent in Réunion Island. The combination of distributional data on threatened species with data on pristine habitats in reserve selection is an efficient and satisfactory approach to overall biodiversity representation (Payet et al., 2010). Payet et al. (2010) developed their study in Réunion Island using the dataset developed for this conservation and restoration plan.

We collected GIS layers on 25 indigenous species, including eight endemic plants, the breeding areas of five oceanic bird species and the distribution areas of nine endemic forest birds, two reptiles and one bat species (Appendix B). The threat status of species was assigned according to the IUCN Red List of Threatened Species (IUCN, 2006). The species data are representative of conservation priorities in the lowlands, although biased toward iconic bird and reptile species.

\subsection{Ecological and evolutionary processes}

Biodiversity in insular regions is sustained and generated by a wide array of ecological processes (such as movements of endemic species) and evolutionary processes (such as speciation processes along altitudinal gradients) (Whittaker et al., 2001). Identifying, mapping and protecting areas supporting such processes are important to guarantee the persistence and long-term evolution of ecosystems. This can be achieved by complementing the network of protected areas by large-scale corridors that represent key ecological linkages between marine, freshwater and terrestrial realms. Corridors are aimed to capture the environmental gradients and maintain landscape connectivity across spatial and temporal scale (Rouget et al., 2006). They facilitate biota movement and maintain evolutionary processes such as geographic speciation (Moritz, 2002).
We used the recently developed map of Spatial Components of Biodiversity Processes (SCBPs) developed by Lagabrielle et al. (2009) in Réunion Island. SCBPs are landscape features supporting key biodiversity processes, such a bird migration, plant dispersal and geographic speciation, along environmental gradients or ecological interfaces (Rouget et al., 2006). Lagabrielle et al. (2009) proposed a method to identify those biodiversity processes and delineate a network of conservation corridors maximising their protection while minimising current and future threats.

SCBPs were mapped as surface elements aligned along linear environmental interfaces or gradients. These comprised oceanic-terrestrial interfaces, riverine corridors, macrohabitat interfaces, topographic unit boundaries, and lowland-upland gradients. The mapping method involved consultation of experts, GIS analysis and an extensive literature review. The transformation status of SCBPs ranked from extant in pristine habitats, through restorable in crop or secondary vegetation, to irreversibly transformed in urban areas.

A regional network of 23 large-scale natural corridors linking sea-level areas to the island summits were designed to encompass a maximum amount of SCBPs and pristine habitats while avoiding areas incompatibles with the maintenance of ecological connectivity (Lagabrielle et al., 2009).

\section{Formulating conservation and restoration targets}

Formulating conservation and restoration targets for biodiversity features is a necessary step toward prioritizing actions (Desmet and Cowling, 2004). A conservation (or restoration) target is a quantitative estimate of the minimum portion of each biodiversity feature that needs to be represented in the conservation (or restoration) protected area network to ensure their long-term persistence (Pressey et al., 2003).

Targets for habitats were expressed as a percentage of their individual original area, i.e. before human transformation. Targets were calculated on original rather than current extents because habitats are typically unequally affected by anthropogenic impacts (Desmet and Cowling, 2004). Targets were then formulated into hectares required per habitat type.

Habitat targets were obtained by summing a baseline target of $20 \%$ and an adjustment target comprised between $0 \%$ and $30 \%$. This composite approach, mixing a fixed and a variable target, is advocated by Rondini and Chiozza (2010). The baseline target of $20 \%$ is in line with international conservation agreements (Convention on Biological Diversity). The adjustment target is driven by local data on the ecological heterogeneity and natural rarity of habitats types. For each habitat type, the adjustment target was calculated as the sum of the following variables (with values scaled from 0 to 10 ): species richness, endemic species richness and environmental heterogeneity. Species richness data were extracted from a previous study by Strasberg et al. (2005). The calculation of the environmental heterogeneity was based on the following parameters: soil type diversity (data from Raunet, 1991) and coefficient of variation of altitude, slope and precipitation. Final habitat targets (baseline + adjustment target) in Réunion rank from $24 \%$ to $45 \%$. Given their uniqueness in the region, the entire current extent of untransformed wetlands and lava flows habitats was targeted (Fig. 2). When the conservation target exceeded the pristine extent of a given habitat, the conservation target was truncated to that extent and the remaining area became the restoration target. Only six pristine habitats ended with a restoration target: five lowland habitats almost fully transformed by urbanisation or agriculture and the subalpine Sophora thicket habitat recently transformed by cattle farming in the uplands.

Conservation targets for species were defined as a fraction of distributional area or number of distributional sites. Targets were 
Table 2

Categories of habitat transformation in Réunion Island.

\begin{tabular}{|c|c|c|c|}
\hline Transformation status & Description & Reference & Area (as \% of total)* \\
\hline \multicolumn{4}{|l|}{ Pristine } \\
\hline Extant & & & 26.9 \\
\hline Pristine & $\begin{array}{l}\text { Not invaded or presence of some alien plant individuals in an } \\
\text { intact canopy and understorey (alien species }<1 \% \text { ) }\end{array}$ & $\begin{array}{l}\text { Strasberg et al. (2005) } \\
\text { Baret et al. (2006) }\end{array}$ & 7.7 \\
\hline Lightly invaded & $\begin{array}{l}\text { Canopy intact (native species cover }>90 \% \text { ) but understorey } \\
\text { invaded }(10-90 \%)\end{array}$ & $\begin{array}{l}\text { Strasberg et al. (2005) } \\
\text { Baret et al. (2006) }\end{array}$ & 19.3 \\
\hline Invaded & & & 25.3 \\
\hline Moderately invaded & $\begin{array}{l}\text { Canopy and understorey invaded } \\
\text { (Native species cover between } 50 \% \text { and } 90 \% \text { in the canopy) }\end{array}$ & $\begin{array}{l}\text { Strasberg et al. (2005) } \\
\text { Baret et al. (2006) }\end{array}$ & 12.8 \\
\hline Highly invaded & $\begin{array}{l}\text { Canopy and understorey invaded } \\
\text { (Native species cover between } 10 \% \text { and } 50 \% \text { in the canopy) }\end{array}$ & $\begin{array}{l}\text { Strasberg et al. (2005) } \\
\text { Baret et al. (2006) }\end{array}$ & 12.5 \\
\hline \multicolumn{4}{|l|}{ Transformed } \\
\hline Restorable & & & 36.3 \\
\hline Secondary vegetation & No native species & Lagabrielle et al. (2009) & 17.7 \\
\hline Cultivated & Crops including forestry & Lagabrielle et al. (2009) & 18.6 \\
\hline Irreversibly transformed & Urban areas & $\begin{array}{l}\text { Urban Planning Agency of } \\
\text { Réunion Island (AGORAH) }\end{array}$ & 9.9 \\
\hline
\end{tabular}

\footnotetext{
${ }^{*}$ The transformation status of $1.6 \%$ of the island's areas remains unknown.
}

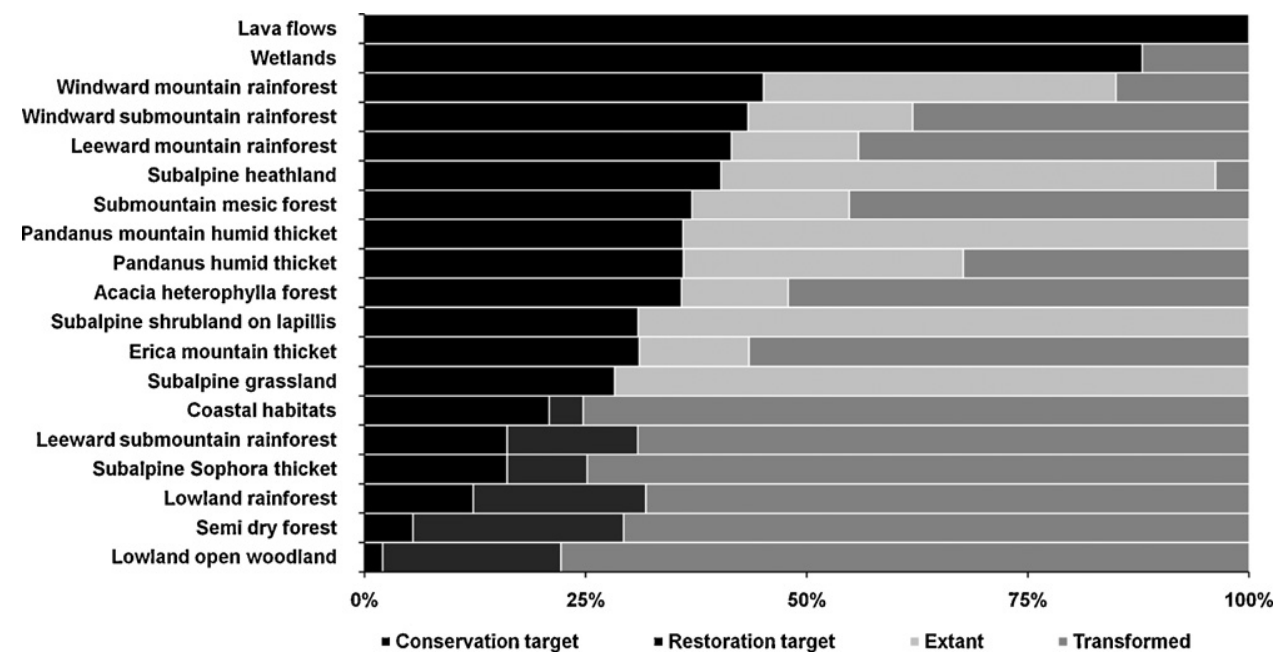

Fig. 2. Conservation and restoration targets for pristine habitat in Réunion Island, expressed as a percentage of the total area of each habitat.

set according to species status in the IUCN Red List of Threatened Species (IUCN, 2006): 100\% for species seriously on the verge of extinction (number of species $=7$ ) or threatened with extinction $(n=4), 80 \%$ for vulnerable $(n=2), 60 \%$ for near threatened $(n=1)$ and $40 \%$ for least concern species ( $n=11$, including two species protected by ministerial decree). Given the low availability of data on species, those targets were arbitrary decided with conservation experts.

All extant and restorable sections of SCBPs and corridors were attributed a $100 \%$ conservation or restoration target given. Those spatial features are required to maintain functional ecosystems on the island (Lagabrielle et al., 2009).

\section{Identifying spatial priorities for conservation and restoration}

\subsection{Site selection process}

The site selection process is aimed at identifying priority sites for conservation and restoration, inside and outside the extant reserve system. This protocol integrates previous systematic conservation planning procedures proposed by Cowling et al. (2003) and Rouget et al. (2006), appended with a systematic restoration planning procedure. A spatial algorithm is used to optimise the site selection process. The eight stages of the site selection process are described in Table 3.

\subsection{Conservation and restoration costs}

As conservation resources are limited, conservation and restoration costs need to be assessed and optimally allocated (Naidoo and Ricketts, 2006). To assess those costs, we developed a Conservation (and restoration) Costs Index (CCI). The CCI is calculated by summing the following cost components: conservation implementation cost (the cost of implementing additional reserves), conservation management cost (the cost of managing protected areas), restoration management cost (the cost of managing habitat restoration, in addition to conservation management cost) and transformation pressure cost (the cost of trying to prevent future probable habitat transformation or destruction by land conversion or invasive species). The CCI variables are detailed in Table 4 . CCI variables and overall values were linearly rescaled from 0 to 100 to facilitate cost analysis, data combination and integration into MARXAN software.

To calculate the transformation pressure cost, the outcomes of three predictive models were combined, i.e. on urbanisation, agricultural and plant invasion potentials. Urbanisation probabilities were derived from non-linear regression analysis on 12 factors explaining urban sprawl observed from 1989 to 2002 (Thinon 
Table 3

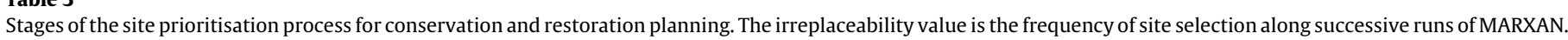

\begin{tabular}{|c|c|}
\hline Stage & Objective \\
\hline \multicolumn{2}{|c|}{ Conservation } \\
\hline 1 & Integrating extant $\mathrm{SCBPs}^{\mathrm{a}}$ outside reserves \\
\hline 2 & Integrating sites of high irreplaceability $(>0.8)$ to achieve conservation targets for habitats, plants and vertebrates inside existing reserves \\
\hline 3 & Integrating sites of high irreplaceability $(>0.8)$ to achieve conservation targets for habitats, plants and vertebrates outside existing reserves \\
\hline 4 & Integrating lowland-upland corridors outside existing reserves \\
\hline \multicolumn{2}{|c|}{ Restoration } \\
\hline 5 & Integrating restorable sections of SCBPs outside existing reserves \\
\hline 6 & Integrating restorable sites of high irreplaceability $(>0.8)$ to achieve restoration targets for habitats inside existing reserves \\
\hline 7 & Integrating restorable sites of high irreplaceability $(>0.8)$ to achieve restoration targets for habitats outside exiting reserves \\
\hline 8 & Integrating restorable sites selected in stages 2,3 and 4 \\
\hline
\end{tabular}

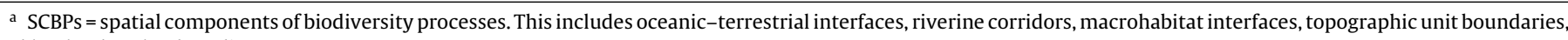
and lowland-upland gradients.

\section{Table 4}

Components of the Conservation Costs Index (CCI). Values range between 0 and 100 .

\begin{tabular}{|c|c|}
\hline Cost component & Rationale \\
\hline Implementation & $\begin{array}{l}\text { Reserve implementation costs depend on land's ownership: public land is cheaper than private land. We considered that land price } \\
\text { were homogeneous in private land }\end{array}$ \\
\hline Conservation management & $\begin{array}{l}\text { Conservation management costs are the investments required to manage protected areas. In insular regions the control of alien plants is } \\
\text { a major conservation management cost (Baret et al., 2006). This cost is minimum in pristine habitats and maximum in invaded habitats. } \\
\text { Other management costs were assumed homogeneous across the landscape: control of poaching activities, maintenance of hiking trails, } \\
\text { etc. }\end{array}$ \\
\hline Restoration management & $\begin{array}{l}\text { Once conserved and managed, the restoration of existing transformed ecosystems involves massive investments. Restoration cost } \\
\text { increases with the level of transformation of ecosystems. This cost is null in pristine habitats and maximum in irreversibly transformed } \\
\text { habitats }\end{array}$ \\
\hline Transformation pressure & $\begin{array}{l}\text { The transformation pressure is the probability of future ecosystem transformation by urbanisation, agriculture and invasive plants. } \\
\text { Dealing with a high transformation probability requires investments (communication, fencing, negotiation and juridical fees among } \\
\text { others) to resist to the transformation pressure. The occurrence probability vary from 'not probable' (score = } 0) \text { to 'highly probable' }(100)\end{array}$ \\
\hline
\end{tabular}

et al., 2007) and calibrated using population projection for 2030. Suitability map for agriculture (sugar cane and pastures, which are the dominant agricultural activities in Réunion Island) were provided by the Chambre Régionale d'Agriculture de La Réunion. Future potential extents of invasive plants were mapped by Baret et al. (2006) using Climatic Envelope Modelling. We summed the potential extent of the 20 most invasive species for this analysis. The transformation pressure probabilities vary from 'not probable' (score $=0$ ) to 'highly probable' $(100)$. We derived the mean score among the three equally weighted factors (urbanisation, agriculture and alien plants) as the final transformation pressure cost. The mean score method was preferred to the highest-score method owing to the high intensity and density of transformation pressures across the planning domain (saturation effect).

\subsection{Identifying optimal sites for conservation and restoration}

To select sites that optimally achieve conservation and restoration targets in the landscape we used the conservation planning software MARXAN (Ball and Possingham, 2000), and its interface CLUZ (Smith, 2004) in Arcview 3.2 (ESRI, Redlands, California).

MARXAN software is designed with the use of stochastic optimisation routines (simulated annealing, Kirkpatrick et al., 1983). The algorithm attempts to identify a near-optimal reserve system, called solution, which best achieves conservation targets while minimising a set of costs (Possingham et al., 2000). Planning units frequently integrated within solutions are the most irreplaceable (MARXAN sensu).

In our case study, the optimisation process aimed to minimize the following three variables when selecting the additional reserve network:

- The "fine" (also called Species Penalty Factor in MARXAN) to be paid if a conservation or restoration target wasn't achieved. We heuristically attributed to this parameter a prohibitive penalty value of 10 million per absent or under-represented biodiversity feature. Thus we ensured that each solution adequately represented all biodiversity features targeted in the plan.

- Second, the average value of the Conservation Costs Index (CCI) within each planning unit. Thus, we ensured that low-cost planning units were preferred to high-cost planning units.

- Third, the Boundary Length Modifier (BLM) which is the overall cost associated with reserve boundaries. Increasing the BLM promotes the compactness of the reserve network identified. The BLM is the sum of all reserve boundaries costs across the planning region. In the model, boundaries costs can be weighted according to the type of reserve boundaries. For instance a boundary with a dense urban areas (less preferable) should inherits a higher weighting factors than a boundary with secondary vegetation (more preferable). In practice, BLM and CCI are highly correlated (i.e. a high surface cost is associated with a high boundary cost). For this reason, and in order to avoid double accounting, boundaries costs weights were set as constant all over the planning region. Thus, the BLM was used as an independant control knob to adjust the overall compacteness of the reserve network, without considering the type of reserve boundaries.

For the purpose of the analysis, the planning domain was divided into hexagonal cells of 10 ha. Hexagonal cells are equidistant and have six adjacent cells when square cells only have four. The hexagonal net was then intersected with the boundaries of the extant statutory reserves, SCBPs and municipalities. The resulting layer is the best compromise between data processing constraints, spatial resolution of input data and compatibility with current land-use planning maps.

\section{Results}

\subsection{Priority sites}

Extant reserves cover $43 \%$ of the area of the island (Fig. 3). Only $50 \%$ of the area of this extant reserve system contributes to 

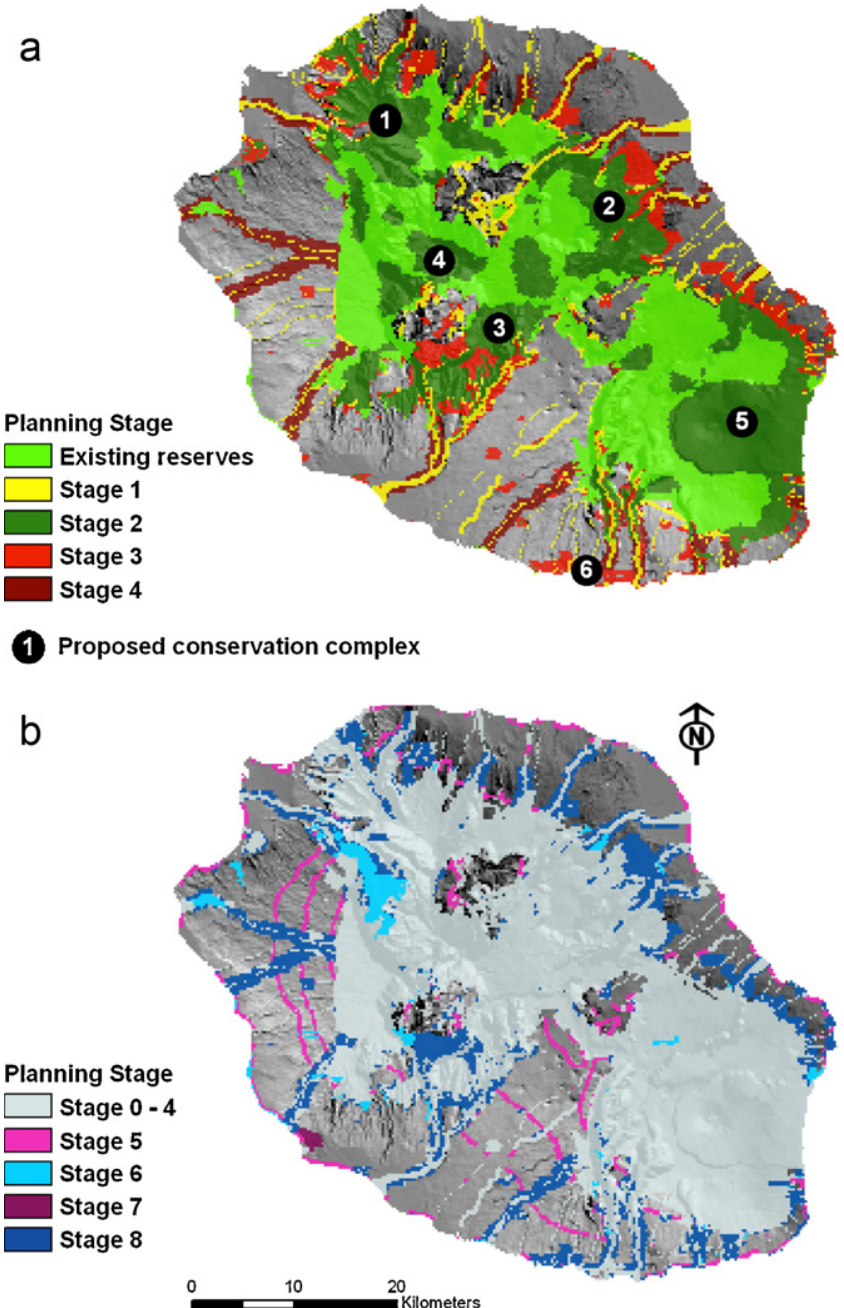

Fig. 3. Priority areas selected along a) the conservation stages (i.e. stages 1-4) and b) restoration stages (5-8). Six priority conservation complexes were identified, namely 1) the Leeward dry complex, 2) windward humid complex, 3) submountain and mountain complex, 4) subalpine complex, 5) active volcano complex, and 6) coastal complex.

achieve conservation and restoration targets (i.e. 50\% of the extant reserve doesn't contribute to achieve targets). This means that half of the area of the National Park is redundant in terms of target achievement. To achieve all targets, in addition to the extant reserve system, $21 \%$ of the island should be protected for conservation or restoration purpose.

The conservation plan requires the protection of an additional $437 \mathrm{~km}^{2}$ of land (17\% of the island). This consists mainly of areas represented in the corridors linking the lowlands to the uplands and on the external margin of the National Park. Based on this analysis, we identified six large conservation complexes that could guide conservation implementation. Those biodiversity complexes comprise priority areas for conservation identified inside and outside the current reserve system (Fig. 3a). The restoration plan requires only an additional $88 \mathrm{~km}^{2}$ of land (4\% of the island), mainly for coastal habitats restoration.

\subsection{Target achievement}

All conservation and restoration targets are predicted to be achieved through the integrated conservation and restoration plan. Within the extant reserves system, 14 habitats (out of 21 ) and 9 vertebrates (out of 17) had their conservation targets achieved but all

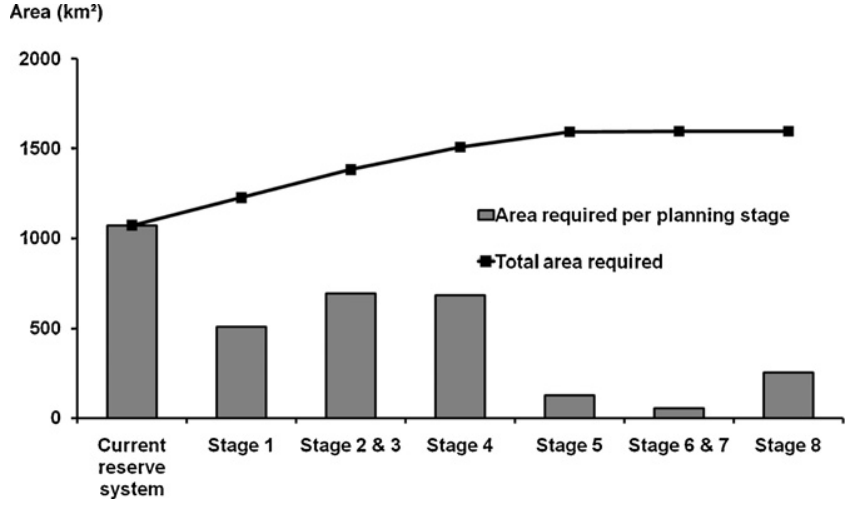

Fig. 4. Area required at each stage of the conservation and restoration plan. The curve of the total area required reaches a plateau at stage 5 since restoration targets could be achieved within zones selected in previous stages.

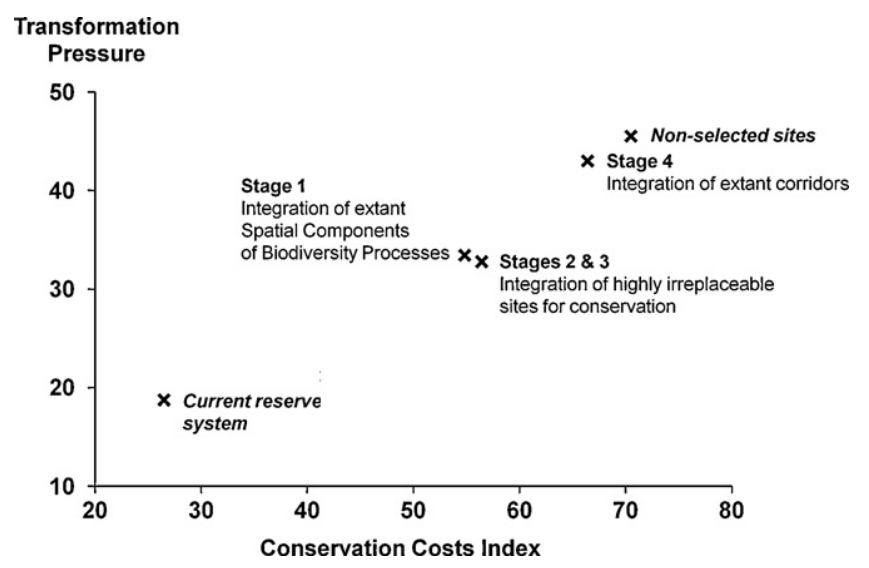

Fig. 5. Mean transformation pressure and conservation costs index in additional areas selected along the stages of the conservation plan. Values range between 0 and 100 .

plants species $(n=8)$ are still under-represented (Table 5). Indeed, these are plants that are distributed in the lowlands, outside the extant reserves system. For some features, over-achievement was substantial. For instance, five habitats had their targets achieved by more than $200 \%$. Almost all restoration targets could be achieved within sites already selected for the conservation plan (Table 5). Indeed, very few additional sites were selected in the restoration plan (Fig. 4).

\subsection{Costs}

The mean value of the Conservation Costs Index (CCI) is 26 inside the extant reserve system against 65 outside (Fig. 5). Highest costs (maximum = 93) are found in the lowlands where habitat transformation by urbanisation, agriculture and invasive plants is highly probable. In additional sites selected for the conservation and restoration plan, the mean $\mathrm{CCI}$ value is 63 whereas this value is 70 in non-selected sites.

The mean CCI value increases in additional areas selected along the planning stages of the conservation plan. Indeed to achieve conservation targets, the site selection is forced to integrate costly sites in the lowlands (high-cost, high pressure). For instance, in stage 1 (SCBPs conservation) the mean CCI value is 54 against 66 in stage 4 (corridors conservation) (Fig. 5). The transformation pressure (i.e. probability of ecosystem transformation) follows the same pattern: low in the extant reserve system $(=19)$ and globally high in non-protected areas located in the lowlands $(=41)$ where conflicts between conservation/restoration interests and other land uses are more likely to occur. Finally, owing to its lower CCI val- 
Table 5

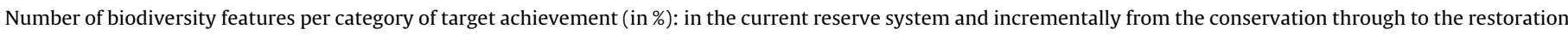
plan.

\begin{tabular}{|c|c|c|c|}
\hline \multirow[t]{2}{*}{ Target achievement category (\%) } & \multicolumn{3}{|l|}{ Number of features } \\
\hline & Current reserve system & Conservation plan & Restoration plan \\
\hline \multicolumn{4}{|l|}{ Habitats (conservation plan) } \\
\hline$<100$ & 6 & 0 & 0 \\
\hline$\geq 100<200$ & 9 & 15 & 15 \\
\hline$\geq 200<300$ & 2 & 2 & 2 \\
\hline$\geq 300$ & 3 & 3 & 3 \\
\hline \multicolumn{4}{|l|}{ Habitats (restoration plan) } \\
\hline$<100$ & 4 & 1 & 0 \\
\hline$\geq 100<500$ & 2 & 5 & 5 \\
\hline$\geq 500<1000$ & 0 & 0 & 0 \\
\hline$\geq 1000$ & 0 & 0 & 1 \\
\hline \multicolumn{4}{|l|}{ Vertebrates (conservation plan) } \\
\hline$<100$ & 8 & 0 & 0 \\
\hline$\geq 100<150$ & 1 & 9 & 9 \\
\hline$\geq 150<200$ & 7 & 0 & 0 \\
\hline$\geq 200$ & 1 & 8 & 8 \\
\hline \multicolumn{4}{|l|}{ Plants (conservation plan) } \\
\hline$<100$ & 8 & 0 & 0 \\
\hline$=100$ & 0 & 8 & 8 \\
\hline
\end{tabular}

ues, the South-West coast of the island has a great potential for restoration.

\section{Discussion}

\subsection{Overview of the planning protocol}

Our planning protocol allows the integration of conservation and restoration planning requirements within a single framework. It also considers the current and future costs associated with the implementation and management of conservation/restoration activities inside and outside reserves. The conservation and restoration plan integrates $64 \%$ of the island, including the existing reserve system. As a point of comparison, the conservation plan designed for the Cape Floristic Region by Cowling et al. (2003) incorporated $49 \%$ of lands.

Despite covering $43 \%$ of the island, the current reserve system (mainly represented by the National Park) has a limited contribution to biodiversity targets. However, the current conservation network needs to be expanded toward the lowlands to conserve a viable sample of all habitats and species. Due to rapid changes in land-use trends, we stress that lowland-upland corridors should be implemented urgently to ensure the persistence of ecological and evolutionary processes along altitudinal gradients. As with many islands, building this network (Jongman, 1995) linking the marine, terrestrial and freshwater realms (Beger et al., 2010) is vital for the persistence of biodiversity in Réunion Island. This lack of protection in the lowlands and this "over-protection" in the uplands highlights the need for proper conservation planning in insular systems.

\subsection{Conservation and restoration costs}

The analysis of conservation costs in Reunion Island reveals that the National Park was implemented in the "cheap uplands" whereas the expansion of protected areas and the implementation of future corridors cannot avoid high-cost areas to achieve conservation targets.

We developed a Conservation Costs Index (CCI) that incorporates current and future costs associated with conservation and restoration activities. A similar approach integrating ecological and socio-economic factors for restoration planning was also recently proposed by Orsi and Geneletti (2010). The integration of costs into the planning process allows the optimisation of conservation and restoration investments in the landscape. The CCI is based on weights attributed to four cost components. Theoretically, modifying those weights could change the outcomes of the plan. Nevertheless, in practice, given the rarity of spatial options in Réunion Island, the main drivers of the site selection process remain the conservation and restoration targets. Indeed, the main contribution of the $\mathrm{CCI}$ is to arbitrate locally between sites that are equivalent in terms of their contribution to the achievement of targets.

To complement this approach, a cost-benefit analysis of conservation activities should be undertaken to balance costs with broader socio-economic benefits arising from ecosystem conservation/restoration. To this purpose, an assessment of ecosystem services would be useful to compare conservation against other spatial planning options such as agriculture or urbanisation. The costs and benefits of different land-use scenarios could then be tested.

\subsection{Data limitations}

The plan rests on limited data on biodiversity features and an incomplete understanding of ecosystem requirements. A major portion of biodiversity patterns and processes still remain cryptic (Gaston and Spicer, 2003). We used distribution data and locality records for a small subset of rare plant and vertebrate species but we did not integrate data on invertebrates which is the largest single component of biodiversity (Redak, 2000). We assumed that habitats act as good environmental surrogates for species but we didn't assess quantitatively this relationship. Furthermore, we delineated habitat units at broad scale $(1: 50,000)$ but finer scale habitats were not explicitly targeted in the plan. In addition, our plan doesn't take into account the intra-taxa diversity (Moritz, 2002).

Our conservation targets are based upon a very rough estimate of biodiversity persistence requirements in Réunion Island. Ideally, conservation targets for habitats should be derived from speciesarea curves and species turn-over but such data are generally not available (Desmet and Cowling, 2004). Targets set for species were based upon their status in the World Red List of Endangered Species. This list is still incomplete, biased toward emblematic species, and status updates are sporadically initiated in small islands. 


\subsection{Implementation strategies}

Three complementary management and implementation strategies should be undertaken in Réunion Island: (1) focusing management interventions inside the National Park on priority areas identified in the plan, (2) expanding the existing reserve system in large low-cost areas located on the margin of the National Park, and (3) focusing investment on a subset of high-cost areas supporting key biodiversity features and processes in the lowlands. To this purpose, an efficient solution would be to focus investments on conservation corridors linking the terrestrial National Park to the marine realm and more particularly the Marine Reserve (Fig. 1). The implementation of the first strategy depends on the National Park authorities but the two others depend directly on the willingness of stakeholders to protect biodiversity outside extant reserves. We propose some implementation mechanisms below.

Expanding the boundaries of the National Park seems currently unrealistic. Rather we suggest integrating conservation measures within the management plan of the Voluntary Stewardship Zone ("Zone de LibreAdhésion") that surrounds the National Park. Municipalities are the members of this zone, which is ruled by a common management charter. Membership is renegotiated every 10 years. In return, municipalities must develop and implement sustainable land-use plans, compatible with biodiversity conservation.

The implementation of corridors will require the integration of heterogeneous land management regimes from the seashore to the summits (Lagabrielle et al., 2009). The implementation of corridor management measures across the landscape should be based on land care and stewardship programmes through financial incentives and training initiatives dedicated to private owners. Such corridors could provide linkages between the Terrestrial National Park and the Marine Natural Reserve on the west coast (Fig. 1). We suggest the implementation of "Inter-realms Corridors" and the creation of "Inter-realms Corridors Management Committees" to mainstream corridors conservation within land management and planning (Beger et al., 2010; Lagabrielle et al., 2009).

\subsection{Experts and stakeholders participation}

In the real world, the 'information-implementation' process expected by conservation scientists rarely happens (Cowling, 2005). Building and maintaining the continuum between conservation and land-use planning is not a trivial task, it requires a stakeholder involvement strategy (Knight et al., 2006). The development of the conservation and restoration plan involved vigorous debate among participants. Some participants argued that the planning process was a waste of time as they already knew where the priority areas for conservation were. For them, the priority wasn't to plan but more to negotiate and implement interventions in zones they already identified. Other participants argued that biodiversity conservation couldn't be entirely considered by quantitative targets. Those participants were also reluctant to use a cost-based approach to conservation planning as they felt it would exclude social issues.

Nevertheless, our plan structured arguments for conservation stakeholders and made them spatially explicit. This is useful to advocate for biodiversity conservation, and to negotiate land allocation with other activity sectors such as agriculture. To this purpose, conservation planning products were presented within a wide array of public arenas, including regional administrations (Regional Scientific Council, Departmental Office of Sensible Natural Sites) and protected areas management institutions (National Forest Office, Coastal Conservation Agency).

Despite an invitation to join the conservation planning process, stakeholders from the urban sector did not participate to the devel- opment of the conservation plan. One possible explanation is that conservation planners were not perceived as neutral holders of scientific knowledge but rather as competing stakeholders in the land-use planning debate. In addition, other issues are considered more important than conservation in the land-use planning debate, in particular the conflict between the agricultural and the urban sector.

\section{Lessons learnt and tips for future applications of the protocol in islands}

Our conservation and restoration planning protocol allows the integration of ecological and socio-economic variables within a single spatial planning framework. It provides spatially explicit guidelines for planning conservation and restoration actions inside and outside an existing reserve system. Our study demonstrates the applicability of this approach in Reunion Island. We believe it is applicable in other insular systems. Other socio-economic variables such as social acceptability and the economic value of ecosystem goods and services could easily be integrated in the proposed protocol.

Conservation planning in insular regions must be based upon low-cost and easily accessible data. This data should be representative of biodiversity patterns and processes and have good spatial coverage. To this purpose, developing a basic map of habitats constitutes an efficient solution, before gathering any other biological data.

Past conservation efforts in islands often focused on low-cost zones, i.e. areas without major socio-economic stakes. Consequently, current reserve networks in islands are often biased toward the upland, whereas coastal biodiversity features and processes are not adequately protected. The disconnection among terrestrial, freshwater and marine realms has become an important threat to the persistence of insular ecosystems. Our method helps finding optimal socio-economic and ecological solutions for maintaining those inter-realms linkages across the landscape. Nevertheless complex conservation planning tools such as MARXAN are not mandatory to develop a conservation plan.

Building a conservation plan requires a homogeneous understanding of coupled ecological and social systems, while acknowledging the complexity of such systems and the limitations of our knowledge. By many aspects, islands depend directly on biodiversity for developing sustainable development strategies. It fosters the role of residents in setting conservation planning priorities and participating fully in the development of their islands. Crosssectoral approaches and involvement of stakeholders are, more than elsewhere, a key component of effective conservation planning in islands.

We consider that our systematic protocol should inform landuse planning but it will never substitute for the land-use planning debate. We believe more in "participation-oriented" approaches rather than pure "GIS product-oriented" procedures to mainstream conservation and restoration issues within land-use planning. Future improvements of the planning protocol should focus on the participation of stakeholders and methods to better-fit conservation planning into existing public decision-making processes

\section{Acknowledgements}

This research was part of the project APIC-BIO, funded by the CIRAD, the Regional Council of Réunion and the European Union (INTERREG 3B, FEDER). APIC-BIO involved the following institutions: CIRAD, University of Réunion Island, South African National Biodiversity Institute, Parc National de la Réunion and Centre of Excellence for Invasion Biology. Erwann Lagabrielle acknowledges 
the African Coelacanth Ecosystem Programme and the National Research Foundation of South Africa for co-funding this work. We thank the following persons who also contributed to this study: Vincent Boullet (Conservatoire Botanique de Mascarin), JeanMichel Probst (Association Nature et Patrimoine), Marc Salamolard (Société d'Etudes Ornithologiques de La Réunion), Mathieu Le Corre (Université de La Réunion), Jean-Michel Sarrailh (CIRAD) and Eric Rivière (CIRAD).

\section{Appendix A.}

See Table A1

\section{Appendix B.}

See Table A2

Table A1

Current and initial area of pristine habitats in Réunion Island. Species richness is for vascular plants (from Strasberg et al., 2005).

\begin{tabular}{|c|c|c|c|c|}
\hline Habitat classes & Current area $\left(\mathrm{km}^{2}\right)$ & Initial area $\left(\mathrm{km}^{2}\right)$ & Species richness & Endemic species richness \\
\hline Erica mountain thicket & 9 & 22 & 90 & 38 \\
\hline Pandanus mountain humid thicket & 41 & 41 & 92 & 36 \\
\hline Subalpine grassland (dry or wet) & 3 & 3 & 34 & 71 \\
\hline Subalpine heath land & 153 & 159 & 30 & 25 \\
\hline Subalpine shrub land on lapillis & 8 & 8 & 30 & 5 \\
\hline Acacia heterophylla forest & 50 & 105 & 96 & 41 \\
\hline Leeward mountain rainforest & 89 & 159 & 144 & 67 \\
\hline Leeward submountain rainforest & 35 & 185 & 142 & 41 \\
\hline Pandanus humid thicket & 20 & 29 & 92 & 38 \\
\hline Windward mountain rainforest & 220 & 259 & 165 & 67 \\
\hline Coastal habitats & 3 & 14 & 35 & 7 \\
\hline Lava flows & 95 & 97 & 53 & 19 \\
\hline Lowland rainforest & 75 & 492 & 127 & 29 \\
\hline Lowland open woodland & 5 & 187 & 41 & 15 \\
\hline Semi dry forest & 35 & 487 & 126 & 30 \\
\hline Subalpine Sophora thicket & 2 & 12 & 11 & 7 \\
\hline Submountain mesic forest & 34 & 61 & 98 & 33 \\
\hline Wetlands & 7 & 8 & 26 & 2 \\
\hline Windward submountain rainforest & 108 & 174 & 166 & 58 \\
\hline
\end{tabular}

\section{Table A2}

Species targeted in the conservation plan.

\begin{tabular}{|c|c|c|c|c|c|}
\hline Species & Scientific name & Endemism ${ }^{\mathrm{a}}$ & IUCN WorldRed list status ${ }^{\mathrm{b}}$ & IUCN regional status ${ }^{\mathrm{b}}$ & Target (\%) \\
\hline \multicolumn{6}{|l|}{ Birds } \\
\hline & Puffinus lherminieri & B & LC & - & 40 \\
\hline & Circus maillardi & B & EN & - & 100 \\
\hline & Pseudobulweria aterrima & B & $\mathrm{CR}$ & - & 100 \\
\hline & Collocalia francica & B, M, Ro & NT & - & 60 \\
\hline & Hypsipetes borbonicus & B & LC & - & 40 \\
\hline & Pterodroma baraui & B & EN & - & 100 \\
\hline & Saxicola tectes & B & LC & - & 40 \\
\hline & Terpsiphone bourbonnensis & B & LC & - & 40 \\
\hline & Zosterops borbonicus & B & LC & - & 40 \\
\hline & Zosterops olivaceus & B & LC & - & 40 \\
\hline & Coracina newtoni & B & EN & - & 100 \\
\hline & Phaeton lepturus & W & LC & - & 40 \\
\hline & Puffinus pacificus & 0 & LC & - & 40 \\
\hline & Phedina borbonica & W & LC & - & 100 \\
\hline \multicolumn{6}{|l|}{ Reptiles } \\
\hline & Phelsuma borbonica & B & - & - & 100 \\
\hline & Phelsuma (ornata) inexpectata & B & - & - & 100 \\
\hline \multicolumn{6}{|c|}{ Mammals } \\
\hline & Mormopterus acetabulosus & 0 & VU & - & 80 \\
\hline \multicolumn{6}{|l|}{ Plants } \\
\hline & Carissa spinarum $L$ & B, M, Ro & - & CR & 100 \\
\hline & Chamaesyce viridula (Cordem. ex Radcl.-Sm.) & B & - & EN & 100 \\
\hline & Delosperma napiforme (N.E. Br.) Schwantes & B & - & VU & 80 \\
\hline & Dombeya populnea (Cav.) Baker & $\mathrm{B}, \mathrm{M}$ & - & $\mathrm{CR}$ & 100 \\
\hline & Gastonia cutispongia Lam. & B & - & CR & 100 \\
\hline & Hernandia mascarenensis (Meisn.) Kubitzki & $\mathrm{B}, \mathrm{M}$ & EN & $\mathrm{CR}$ & 100 \\
\hline & Obetia ficifolia (Poir.) Gaudich. & B, M, Ro & - & CR & 100 \\
\hline & Pemphis acidula J.R. Forst. et G. Forst. & 0 & - & $\mathrm{CR}$ & 100 \\
\hline
\end{tabular}

a B = Réunion ("Bourbon”), M = Maurice, Ro = Rodrigue, W= West Indian Ocean (including Madagascar), $0=$ Other.

b $\mathrm{CR}=$ seriously on the verge of extinction, $\mathrm{EN}=$ threatened of extinction, $\mathrm{VU}=$ vulnerable, $\mathrm{NT}=$ near threatened, $\mathrm{LC}=$ least concern. 


\section{References}

Ball, I.R., Possingham, H.P., 2000. MARXAN (V1.8.2): Marine Reserve Design Using Spatially Explicit Annealing, A Manual.

Balmford, A., 2003. Conservation planning in the real world: South Africa is showing the way. Trends Ecol. Evol. 18 (9), 435-438.

Baret, S., Rouget, M., Richardson, D.M., Lavergne, C., Egoh, D., Dupont, J., et al., 2006. Current distribution and potential extent of the most invasive alien species on La Réunion (Indian Ocean Mascarene islands). Austral. Ecol. 31, 747-758.

Beger, M., Grantham, H.S., Pressey, R.L., Wilson, K.A., Peterson, E.L., Dorfman, D., Mumby, P.J., Lourival, R., Brumbaugh, D.R., Possingham, H.P., 2010. Conservation planning for connectivity across marine, freshwater, and terrestrial realms. Biol. Conserv. 143 (3), 565-575.

Cadet, T., 1980. La végétation de l'île de La Réunion, étude phytoécologique et phytosociologique (Vegetation of Réunion Island, phytoecological and phytosociologicalstudy). Ph.D. thesis, Université d'Aix Marseille, France (in French).

Case, T.J., Bolger, D.L., Richman, A.D., 1992. Reptilian extinctions: the last ten thousand years. In: Fiedler, P.L., Jain, S.K. (Eds.), Conservation Biology: The Theory and Practice of Nature Conservation, Preservation, and Management. Chapman and Hall, New York, USA, pp. 91-125.

Conservatoire Botanique National de Mascarin, 2008. Version électronique de l'Index de la flore vasculaire de la Réunion (Trachéophytes): statuts, menaces et protections (Electronic version of the vascularflora Index of Réunion Island (Tracheophytes): status, threats and protections). [On line] URL: http://flore.cbnm.org. Last access date: 21 April 2010 (in French).

Cook, J.A., Dawson, N.G., MacDonald, S.O., 2006. Conservation of highly fragmented systems: the north temperate Alexander Archipelago. Biol. Conserv. 133, 1-15.

Cowling, R.M., 2005. Maintaining the research-implementation continuum in conservation. Soc. Conserv. Biol. Newsl. 12 (4), 1-19 [online] URL: www.conbio. org/Publications/Newsletter/Archives/2005-9a-November/v12n4.rtf, Last access date: 21 April 2010.

Cowling, R.M., Pressey, R.L., Rouget, M., Lombard, A.T., 2003. A conservation plan for a global biodiversity hotspot - the Cape Floristic Region, South Africa. Biol. Conserv. 112 (1-2), 191-216.

Cudihhy, L.W., Stone, C.P., 1990. Alteration of native Hawaiian vegetation, effects of human, their activities and introductions. In: Cooperative National Park Resources Studies Unit, University of Hawaii at Manoa, Honolulu, USA.

Desmet, P., Cowling, R.M., 2004. Using the species-area relationship to set baseline targets for conservation. Ecol. Soc. 9 (2), 102-124.

Diamond, J.M., 1989. The present, past and future of human caused extinctions. Philos Trans. R. Soc. B 325, 469-477.

Dolisca, F., McDaniel, J.M., Teeter, L.D., Jolly, C.M., 2007. Land tenure, population pressure, and deforestation in Haiti: the case of Forêt des Pins Reserve. J. Forest. Econ. 13, 277-289.

Durieux, L., Lagabrielle, E., Andrew, N., 2008. A method for monitoring building construction in urban sprawl areas using object-based analysis of Spot 5 images and existing GIS data. ISPRS J. Photogramm. 63, 399-408.

Fritts, T.H., Rodda, G.H., 1998. The role of introduced species in the degradation of island ecosystems. Annu. Rev. Ecol. Syst. 29, 113-140.

Gaston, K.J., Spicer, J.I., 2003. Biodiversity An introduction. Blackwell Science, Oxford, UK.

Gigord, L., Picot, F., Shykoff, J., 1999. Effects of habitat fragmentation on Dombeya acutangula (Sterculiaceae), a native tree on La Réunion (Indian Ocean). Biol. Conserv. $88,43-51$.

Grenier, C., 2000. Conservation Contre Nature (Conservation Against Nature), IRD ed. Collection Latitudes 23, Paris, France (in French).

INSEE, 2009. Recensement général de la population française (General census of the French population). [online] URL: www.insee.fr. Last access date: 21 April 2010, (in French).

IUCN, 2006. IUCN Red List of Threatened Species. IUCN, Gland, Switzerland and Cambridge, UK. [On line] URL: www.iucnredlist.org. Last access date: 21 April 2010.

Jongman, R.H.G., 1995. Nature conservation planning in Europe: developing ecological networks. Landsc. Urban Plan. 32, 169-183.

Kirkpatrick, S., Gelatt, C., Vecchi, M., 1983. Optimisation by simulated annealing. Science 220, 671-680.

Knight, A.T., Cowling, R.M., Campbell, B.M., 2006. An operationnal model for implementing conservation action. Conserv. Biol. 20 (2), 408-419.

Lagabrielle, E., Botta, A., Daré, W., David, D., Aubert, A., Fabricius, C., 2010. Modelling with stakeholders to integrate biodiversity conservation into land-use planning - lessons learnt in Réunion Island (Western Indian Ocean). Environ. Modell. Softw., doi:10.1016/j.envsoft.2010.01.011.

Lagabrielle, E., Rouget, M., Durieux, L., Payet, K., Wistebaar, T., Baret, S., et al., 2009. Identifying and mapping biodiversity processes for conservation planning in islands. A case study in Réunion Island (Western Indian Ocean). Biol. Conserv. 142 (7), 1523-1535.
Lombard, A.T., Cowling, R.M., Pressey, R.L., Rebelo, A.G., 2003. Effectiveness of land classes as surrogates for species in conservation planning for the Cape Floristic Region. Biol. Conserv. 112 (1-2), 45-62.

MacDonald, I.A.W., Thébaud, C., Strahm, W.A., Strasberg, D., 1991. Effects of alien invasions on native vegetation remnants on La Réunion (Mascarenes Islands IndianOcean). Environ. Conserv. 18 (1), 51-61.

Margules, C.R., Pressey, R.L., 2000. Systematic conservation planning. Nature 405 243-253.

Moritz, C., 2002. Strategies to protect biological diversity and the evolutionary processes that sustain it. Syst. Biol. 5, 238-254.

Mittermeier, R.A., da Fonseca, G.A.B., Hoffman, M., Pilgrim, J., Brooks, T., Gill, P.R et al., 2005. Hotspots revisited: Earth's biologically richest and most endangered terrestrial ecoregions. In: CEMEX, Conservation International, Washington DC USA.

Mourer-Chauvire, C., Bour, R., Ribes, S., Moutou, F., 1999. The avifauna of Réunion Island (Mascarene Islands) at the time of arrival of the first Europeans. Avian Paleontology at the Closes of the 20th Century. Washington, DC, USA, 4-7 June 1996. Smithsonian Contributions to Paleobiology.

Mueller-Dombois, D., Loope, L.L., 1990. Some unique ecological aspects of oceanic island ecosystems. Monog. Syst. Botan. 32, 21-28.

Naidoo, R., Ricketts, T.H., 2006. Mapping the economic costs and benefits of conservation. PLoS Biol. 4 (11), e360, doi:10.1371/journal.pbio.0040360.

Novy-Hildesley, J.W., 2001. Incentive Measures for Conservation of Biodiversity and Sustainability: A Case Study of the Galapagos Islands. UNEP/WWF, USA [On line] URL: http://www.cbd.int/doc/case-studies/inc/cs-inc-ec-galapagos-en.pdf, Last access date: 21 April 2010.

Orsi, F., Geneletti, D., 2010. Identifying priority areas for forest landscape restoration in Chiapas (Mexico): an operational approach combining ecological and socioeconomic criteria. Landsc. Urban Plan. 94 (1), 20-30.

Payet, K., Rouget, M., Lagabrielle, E., Esler, K.J., 2010. Measuring the effectiveness of regional biodiversity surrogates at representing local biodiversity: a real-world case study in Réunion Island (Indian Ocean). Austral. Ecol. 35, 121-133.

Possingham, H.P., Ball, I.R., Andelman, S., 2000. Mathematical methods for identifying representative reserve networks. In: Ferson, S., Burgman, M. (Eds.) Quantitative Methods for Conservation Biology. Springer-Verlag, New York, USA, pp. 291-305.

Pressey, R.L., Cowling, R.M., Rouget, M., 2003. Formulating conservation targets for biodiversity pattern and process in the Cape Floristic Region, South Africa. Biol. Conserv. 112 (1-2), 99-127.

Raunet, M., 1991. Le milieu physique et les sols de l'île de la Réunion (Physical Environment and Soils of Réunion Island). CIRAD, Montpellier, France (in French).

Redak, R.A., 2000. Arthropods and multispecies habitat conservation plans: are we missing something? Environ. Manage. 26 (1), 97-107.

Roberts, C.M., Mcclean, C.J., Veron, J.E.N., Hawkins, J.P., Allen, G.R., Mcallister, D.E., et al., 2002. Marine biodiversity hotspots and conservation priorities for tropical reefs. Science 295 (5558), 1280-1284.

Rondini, C., Chiozza, F., 2010. Quantitative methods for defining percentage area targets for habitat types in conservation planning. Biol. Conserv. 143 (7), 1646-1653.

Rouget, M., Cowling, R.M., Lombard, A.T., Knight, A.T., Kerley, G.I.H., 2006. Designing large-scale conservation corridors for pattern and process. Conserv. Biol. 20 (2), 549-561.

Simberloff, D., 1995. Why do introduced species appear to devastate islands more than mainland areas? Pac. Sci. 18, 130-137.

Smith, R.J., 2004. Conservation Land-Use Zoning (CLUZ) Software.

Stattersfield, A., Capper, D., 2000. Threatened Birds of the World. Birdlife International, Cambridge, UK.

Strasberg, D., Rouget, M., Richardson, D.M., Baret, S., Dupont, J., Cowling, R.M., 2005. An assessment of habitat diversity, transformation and threats to biodiversity on Réunion Island (Mascarene Islands, Indian Ocean) as a basis for conservation planning. Biodivers. Conserv. 14 (12), 3015-3032.

Thinon, P., Martignac, C., Metzger, P., Cheylan, J.-P., 2007. Analyse géographique et modélisation des dynamiques d'urbanisation à La Réunion (Geographicanalysis and modelling of urbandynamics in Réunion Island). Cybergeo 389. [On line] URL: http://www.cybergeo.eu/index8692.html. Last access date: 21 April 2010 , (in French).

van der Valk, A., 2002. The Dutch planning experience. Landsc. Urban Plan. 58 (2), 201-210.

Veech, J.A., 2003. Incorporating socio economic factors into the analysis of biodiversity hotspots. Appl. Geogr. 23, 73-78.

Whittaker, R.J., Willis, K.J., Field, R., 2001. Scale and species richness: toward a general, hierarchical theory of species diversity. J. Biogeogr. 28, 453-470.

Young, D., 2004. Our Islands, Our Selves: A History of Conservation in New Zealand. Otago University Press, in association with the Department of Conservation and the Ministry for Culture and Heritage, Dunedin, New Zealand. 